\title{
Formal Service Learning Opportunities: Engineering Internships in Social Entrepreneurship Organizations
}

\author{
Camilla M. Saviz, Ph.D., P.E. \\ Associate Professor, Department of Civil Engineering \\ University of the Pacific \\ Stockton, CA 95211 \\ csaviz@pacific.edu \\ Abel A. Fernandez, Ph.D., P.E. \\ Professor and Director, Engineering Management Program \\ University of the Pacific \\ Stockton, CA 95211 \\ afernandez@pacific.edu \\ Elizabeth A. Basha, Ph.D. \\ Assistant Professor, Department of Electrical and Computer Engineering \\ University of the Pacific \\ Stockton, CA 95211 \\ ebasha@pacific.edu
}

\begin{abstract}
Over the past three years, a collaboration between the School of Engineering and Computer Science and the Global Center for Social Entrepreneurship at the University of the Pacific has provided students with internship opportunities at five different social entrepreneurship organizations distributed among six countries. The summer internship program administered by the Global Center seeks to provide an enriching experience for participants, to raise awareness of the broad application of social entrepreneurship across different disciplines, and provide qualified student assistance to organizations seeking specific help. Working with the socially entrepreneurial organization, students were required to apply problem-solving skills in environments where language, culture, technical support, and supervision were very different from levels experienced during their more 'traditional' internships in the United States. These internships in social entrepreneurship allowed students to learn first-hand that successfully implementing projects in other countries requires strong technical skills and a fundamental understanding of local cultural, political, and contextual factors. At the institutional level, lessons learned included the importance of forming strategic partnerships to increase opportunities and capitalize on limited resources, and the need to use existing frameworks to facilitate student involvement in such service-learning opportunities.
\end{abstract}

Index Terms - social entrepreneurship, service learning, internships

\section{INTRODUCTION}

The "Engineer of 2020", as described by the National Academy of Engineering ${ }^{1}$, must be "prepared to adapt to changes in global forces and trends and to ethically assist the world in 
creating a balance in the standard of living for developing and developed countries alike." The challenge for engineering programs is to provide a framework within which students can develop an awareness of needs within a global context and apply their knowledge and skills within that context. Another concern for programs is to demonstrate that students have "the broad education necessary to understand the impact of engineering solutions in a global, economic, environmental, and societal context," as required by the ABET Accreditation Criteria for Engineering programs ${ }^{2}$. Engineering internships abroad, and particularly within typically less technically-oriented environment of a social entrepreneurship organization, provide a means for gauging whether students gain the appropriate skills through their engineering educational program.

Universities have responded to students' interest in service learning and the need to prepare students for successful contributions in a global society in many different ways. Some programs have developed courses, degree programs, and extra-curricular opportunities focused on the socio-technical aspects of engineering. A number of universities offer courses on design of context-appropriate technology appropriate for the developing world ${ }^{3-6}$. Several innovative courses and programs integrate the social benefit of engineering as the central theme ${ }^{7-11}$, while other universities provide formal programs for students to go abroad for study, work, or service learning ${ }^{12-14}$. Service learning has taken many forms within engineering programs and has been found to assist in students' professional development ${ }^{15-19}$. At some institutions, globallyfocused engineering student organizations, such as Engineers Without Borders and Engineers for a Sustainable World, reflect students' growing interest in international development, eradication of poverty, environmental action, and application of technology for social benefit ${ }^{20-21}$. Some of these programs are linked to an academic component and help in identification of meaningful undergraduate or graduate-level projects ${ }^{22-23}$. At least one program provides a scholarship and academic credit to students with financial needs, and in return, requires students to complete 150 hours of work with local nonprofits as part of a service-learning co-operative education program ${ }^{24-25}$.

However, the issue of sustainability of such efforts in terms of student and faculty time and university resources is not yet resolved ${ }^{26}$. Sustainability of these socially-focused academic and experiential learning programs is an important issue where limited resources constrain new initiatives, particularly in the current era of shrinking resources. As educational costs continue to rise and availability of scholarships and other financial aid decreases, programs are facing calls to reduce costs or increase tuition, in either case impacting students ${ }^{27}$. Thus, socially-focused programs must also consider the realities of impacted engineering curricula and availability of time within a student's curriculum to prepare for and complete an internship abroad.

The issues of sustainability in terms of student and faculty time and availability of resources can be addressed in part through strategic partnerships with existing programs and by working within existing frameworks, capitalizing on resources and diverse capabilities offered by each partner entity. Socially-focused curricula have traditionally been the purview of liberal arts programs, with established procedures, student involvement and funding. This is the case at the University of the Pacific, an institution with a strong liberal arts tradition, where the Global Center for Social Entrepreneurship ("Global Center") is the central hub of social entrepreneurship activities. A strong collegial relationship over between the Director of the Global Center and engineering faculty led to a collaborative effort to identify pioneering engineering students who would benefit from, and who could help enhance, the Center's social entrepreneurship summer internship program. This partnership benefits engineering students, 
expands the Center's multidisciplinary span, and provides a natural linkage between engineering education and social entrepreneurship.

The School of Engineering and Computer Science (SOECS) has a well-established cooperative education program ${ }^{28}$. All students who are citizens of the United States must complete a minimum 32 units of "co-op" - paid, practical experience equivalent to a seven month period as a requirement for graduation. Permanent U.S. residents and international students are encouraged to participate in the program, but are not required to do so. Students prepare for the experience through an intensive program that includes a professional practice course, resume preparation, mock interviews, and a competitive interview and hiring process. Although many employers conduct the interviews in-person and on campus, technology has facilitated other means of evaluating and selecting candidates. Students are also free to secure their own co-op through other means, although any prospective internship must be vetted by the Director of Cooperative Education to ensure that the experience will meet the learning outcomes established for the program. Typically, students will stay within the same organization for the entire seven month period, but some choose to broaden their experience and divide their time between organizations of different size (e.g., large vs. small) or structure (e.g., public vs. private). The co-op program provided a useful existing framework within which the internships in social entrepreneurship could be implemented.

This paper describes a partnership linking the School of Engineering and Computer Science's existing co-operative education program to the Global Center's service learning internship program. The paper describes the respective program of each unit, analyzes the hybrid program developed, and explains the learning outcomes and assessment techniques for measuring student performance. The paper concludes with discussion of planned improvements and suggestions for creating these types of strategic working partnerships.

\section{Developing Strategic Partnerships: The Ambassador Corps Fellowship Program}

Social entrepreneurship is a hybrid innovation that applies business and management skills to tackle chronic societal problems with sustainable solutions. The mission of the Global Center for Social Entrepreneurship is to actively engage the university community in all aspects of this field through academic curricula, internships and apprenticeships, applied research, local and global community outreach, and career development. Through its program of activities, the Global Center seeks to develop solution-minded pragmatists who are pioneering practical, inventive, and sustainable approaches to address the world's most pressing social issues: poverty, disease, malnutrition, environmental degradation, injustice, and illiteracy. The Global Center has an active and engaged Board of Stakeholders whose members provide strategic planning, student mentorship, programmatic development, student internship opportunities, curriculum development, strategic alliance networking, and financial support. The Board comprises 20 professionals that include recognized social entrepreneurs, corporate CEOs, non-profit directors, foundation presidents, microfinance specialists, venture capitalists, academicians, and individuals with expertise in management and fundraising.

In Academic Year (AY) 2008-09, the Global Center for Social Entrepreneurship initiated the Ambassador Corps Fellowship Program - a summer internship and fellowship program to place up to fifteen students in social entrepreneurship organizations in emerging countries. In addition to the hands-on and cultural experiences, the "Ambassador Corps" program included a one-week pre-trip immersion workshop focused on essential fundamentals for addressing issues in the international arena, cultivating professional relationships in developing countries, and learning 
about the role of business and management in the context of socially-focused enterprises. Students traditionally associated with the Center were studying in majors such as modern languages and international relations, where an experience abroad was already a requirement for graduation. To broaden the Center's student base, the Director of the Global Center and engineering faculty actively recruited engineering applicants to the summer internship program. It was expected that some engineering students would be receptive to the program as it not only involved socially-beneficial engineering-related work in the international arena but could also satisfy, in part, the co-operative experience requirement for graduation. A natural partnership formed because some engineering students were interested in travelling abroad and working in international development or service-focused fields.

Of the ten fellowships awarded in the first year, two were awarded to engineering students who completed eight-week internships at different non-governmental organizations, both coincidentally in South Africa. In AY 2009-10, engineering students were selected for three of fifteen fellowships awarded. The three students worked with different organizations on three continents. In AY 2010-2011, one engineering student was awarded a fellowship. Using connections established by an engineering student during the previous summer, the student worked with the same non-governmental organization partner, but in a different country. Although not part of the Ambassador Corps program, another student completed an internship with a faith-based organization during Summer 2008. The organizations and their locations are summarized in Table 1, as are the socially entrepreneurial features of each. The internship assignments at the various organizations are shown in Table 2 together with the respective technical and professional skills students needed to perform their duties. As indicated in Table 2, the students represented four different majors and two different degree programs. Each experience required that students apply their engineering skills although the use of these skills often occurred in a different context than the students were used to through their engineering coursework. In all cases, student interns were immersed in an unfamiliar socio-political environment where success also depended on adaptability, self-motivation, and an ability to work within different cultural and professional norms.

Global Center staff identified internship opportunities through their contacts with social entrepreneurship and non-profit organizations located worldwide. To qualify as a co-operative educational experience, each assignment identified for engineering students had to principally involve engineering-related work. The Center staff counseled fellowship candidates on placement options, and in some cases, consulted with engineering faculty to ensure that the placement involved engineering work that would be meaningful to the student and useful for the partner organization. Each candidate conducted further research on the prospective social entrepreneurship organizations and contacted personnel at the organizations via email, telephone, or online conference to address initial questions. The student and the organizations made final selections in consultation with Global Center staff considering academic experience, language requirements, and appropriate fit between the student's academic interest and the mission of the social entrepreneurship organization. A Memorandum of Understanding developed for each student articulated responsibilities on the part of both the student and the host organization. Selection processes, funding, program logistics, and details about three students' experiences are described further by Saviz, et al. ${ }^{19}$.

Jue ${ }^{18}$ suggests that factors leading to successful experiences and sustainable projects include building a multidisciplinary team, collaborating with a solid community partner, and preparing for continuity. As shown in Table 2, students used engineering and professional skills, and 
worked predominantly with members of the local community for the duration of their internship. In each case, students worked on projects identified by the partner organizations, were mentored or supervised by a member of the organization in which the student was placed, and helped on projects that directly benefitted the sustainability of the organization or addressed its mission. Leaders within the partner organizations were especially eager and pleased to work with engineering students because of the students' technical backgrounds and problem-solving skills.

Table 1. Summary of internships in Social Entrepreneurship Organizations

\begin{tabular}{|c|c|c|}
\hline Organization & Location & Income sources \& social entrepreneurship focus of organization \\
\hline AVINA & Santa Cruz, Bolivia & Sustainable development, capacity building, water infrastructure. \\
\hline AVINA & Asuncion, Paraguay & Sustainable development, capacity building, water infrastructure. \\
\hline $\begin{array}{l}\text { Cheetah } \\
\text { Conservation Fund }\end{array}$ & $\begin{array}{l}\text { Near Otjiwarongo, } \\
\text { Namibia }\end{array}$ & $\begin{array}{l}\text { Eco-tourism, cheetah conservation research and education } \\
\text { programs, conservation farming practices, small business ventures } \\
\text { (goat cheese \& biofuel production) }\end{array}$ \\
\hline Eden Campus & $\begin{array}{l}\text { Karatara, } \\
\text { South Africa }\end{array}$ & Eco-tourism, sustainable agriculture education and production \\
\hline Maharishi Institute & $\begin{array}{l}\text { Johannesburg, } \\
\text { South Africa }\end{array}$ & Education, call-center training and operation \\
\hline SPARC & Bangalore, India & $\begin{array}{l}\text { Microfinance, slum boundary mapping, developing sustainable } \\
\text { housing and infrastructure for underserved communities }\end{array}$ \\
\hline $\begin{array}{l}\text { Engineering } \\
\text { Ministries } \\
\text { International }\end{array}$ & Colorado \& Rwanda & $\begin{array}{l}\text { Building schools, churches, community centers; water supply and } \\
\text { sanitation systems }\end{array}$ \\
\hline
\end{tabular}

Using and Adapting Existing Frameworks: The Co-operative Education Program

The co-operative education program ("co-op") was established in 1970 and remains an integral component of undergraduate engineering curricula in the School of Engineering and Computer Science. The co-op provides students with opportunities to apply their knowledge in a full-time, paid position in their area of interest and is designed to complement and enhance the student's academic program. As such, students are expected to engage in engineering-related work consistent with their academic preparation. While on co-op, students' duties may include design, drafting, inspection, construction, field work, report preparation, or public speaking - activities in which practicing engineers are also typically engaged. 
Table 2. Summary of Students' Duties and Skills Utilized in Internships

\begin{tabular}{|c|c|c|c|c|c|}
\hline Organization & Student's Major & Student Duties & Community Involvement & Engineering Skills Used & Professional Skills Used \\
\hline AVINA & $\begin{array}{l}\text { Civil } \\
\text { Engineering } \\
\text { (B.S.), } \\
\text { Engineering } \\
\text { Science (M.S.) }\end{array}$ & $\begin{array}{l}\text { Interviewed leaders of } \\
\text { community water } \\
\text { organizations, compiled and } \\
\text { analyzed data, helped plan \& } \\
\text { coordinate an international } \\
\text { water conference }\end{array}$ & $\begin{array}{l}\text { Met with and interviewed } \\
\text { community leaders on water } \\
\text { needs; worked in urban and rural } \\
\text { environments }\end{array}$ & $\begin{array}{l}\text { Gathered and analyzed } \\
\text { data; analyzed water } \\
\text { supply infrastructure }\end{array}$ & $\begin{array}{l}\text { Oral and written } \\
\text { communication; project } \\
\text { planning; community } \\
\text { outreach; leadership and } \\
\text { professional development }\end{array}$ \\
\hline AVINA & $\begin{array}{l}\text { Civil } \\
\text { Engineering } \\
\text { (B.S.), } \\
\text { Engineering } \\
\text { Science (M.S.) }\end{array}$ & $\begin{array}{l}\text { Reviewed and designed water } \\
\text { supply system expansion in a } \\
\text { rural community, helped } \\
\text { organize the first annual } \\
\text { National Water Conference }\end{array}$ & $\begin{array}{l}\text { Site visits to rural communities; } \\
\text { worked with community leaders } \\
\text { on water supply project } \\
\text { expansion }\end{array}$ & $\begin{array}{l}\text { Obtained community } \\
\text { input on system needs; } \\
\text { analyzed water supply } \\
\text { infrastructure, designed } \\
\text { water supply pipe }\end{array}$ & $\begin{array}{l}\text { Oral and written } \\
\text { communication; project } \\
\text { planning; leadership and } \\
\text { professional development }\end{array}$ \\
\hline $\begin{array}{l}\text { Cheetah } \\
\text { Conservation } \\
\text { Fund }\end{array}$ & $\begin{array}{l}\text { Engineering } \\
\text { Management } \\
\text { (B.S.), } \\
\text { Engineering } \\
\text { Science (M.S.) }\end{array}$ & $\begin{array}{l}\text { Evaluated production } \\
\text { processes, analyzed data; } \\
\text { Business planning, Cheetah } \\
\text { care }\end{array}$ & $\begin{array}{l}\text { Remote location due to facility } \\
\text { focus on animal conservation. } \\
\text { Worked with local community } \\
\text { members on cheetah care and } \\
\text { goat cheese and biofuel } \\
\text { production businesses }\end{array}$ & $\begin{array}{l}\text { Gathered data, analyzed } \\
\text { industrial processes, } \\
\text { suggested improvements } \\
\text { for process and efficiency }\end{array}$ & $\begin{array}{l}\text { Oral and written } \\
\text { communication; } \\
\text { multidisciplinary team } \\
\text { interaction; business } \\
\text { planning and marketing }\end{array}$ \\
\hline Eden Campus & $\begin{array}{l}\text { Mechanical } \\
\text { Engineering } \\
\text { (B.S.) }\end{array}$ & $\begin{array}{l}\text { Construction, Taught } \\
\text { agricultural practices, } \\
\text { Business development }\end{array}$ & $\begin{array}{l}\text { Worked with local community } \\
\text { members on agricultural } \\
\text { projects, youth education }\end{array}$ & $\begin{array}{l}\text { Planned and implemented } \\
\text { small construction } \\
\text { projects; taught students }\end{array}$ & $\begin{array}{l}\text { Oral and written } \\
\text { communication; business } \\
\text { planning }\end{array}$ \\
\hline $\begin{array}{l}\text { Maharishi } \\
\text { Institute }\end{array}$ & $\begin{array}{l}\text { Bioengineering } \\
\text { (B.S.), } \\
\text { Engineering } \\
\text { Science (M.S.) }\end{array}$ & $\begin{array}{l}\text { Database implementation, data } \\
\text { management, leadership } \\
\text { instruction and development }\end{array}$ & $\begin{array}{l}\text { Worked with local instructors, } \\
\text { administrators; taught local } \\
\text { urban students }\end{array}$ & $\begin{array}{l}\text { Gathered, organized, and } \\
\text { analyzed enrollment data } \\
\text { and statistics, developed } \\
\text { enrollment database }\end{array}$ & $\begin{array}{l}\text { Oral and written } \\
\text { communication; } \\
\text { leadership development }\end{array}$ \\
\hline SPARC & $\begin{array}{l}\text { Civil } \\
\text { Engineering } \\
\text { (B.S.) }\end{array}$ & $\begin{array}{l}\text { Biometric data collection and } \\
\text { analysis, GPS mapping, } \\
\text { Database implementation }\end{array}$ & $\begin{array}{l}\text { Gathered data in local } \\
\text { community, attended community } \\
\text { meetings; worked in office with } \\
\text { local women to set up database }\end{array}$ & $\begin{array}{l}\text { Gathered, organized, and } \\
\text { analyzed data to map } \\
\text { slum communities; used } \\
\& \text { modified GIS database }\end{array}$ & $\begin{array}{l}\text { Oral and visual } \\
\text { communication; } \\
\text { multidisciplinary team } \\
\text { interaction }\end{array}$ \\
\hline $\begin{array}{l}\text { Engineering } \\
\text { Ministries } \\
\text { International }\end{array}$ & $\begin{array}{l}\text { Civil } \\
\text { Engineering } \\
\text { (B.S.) }\end{array}$ & Surveying, Mapping & $\begin{array}{l}\text { Community meetings and } \\
\text { interaction on proposed projects }\end{array}$ & $\begin{array}{l}\text { Surveying; compiled data } \\
\text { for water system and } \\
\text { construction projects }\end{array}$ & $\begin{array}{l}\text { Oral, written, and visual } \\
\text { communication; } \\
\text { multidisciplinary team } \\
\text { interaction }\end{array}$ \\
\hline
\end{tabular}


Engineering students who are United States citizens, must earn a minimum of 32 units of co-op or 'professional practice' in addition to the minimum 120 units of academic work required for graduation. Permanent U.S. residents and international students are strongly encouraged participate in the co-op program, but are not required to do so. The 32 co-op units may be earned over a continuous seven-month period (i.e., one academic semester plus a summer), over two summer periods, or over any other combination that fits the student's curriculum plan, interests, and constraints. Students are generally encouraged, when possible, to seek a sevenmonth co-op as the longer period typically provides opportunities to work on more in-depth projects, benefitting both the student and the organization.

In 2008, in response to increased student interest in service-learning, working in emerging countries or with non-governmental organizations, a set of criteria were developed to determine whether a student's proposed experience qualified for consideration as a co-op. Eligible experiences meet all of the following criteria:

1. Must be under the aegis of a bona fide organization.

2. Student must a priori submit a plan of activities during the work assignment. The plan should be initiated at least six months before the planned activity, allowing students ample time to conduct a normal co-op search in the event the proposal is not acceptable.

3. The planned activity should be related to the student's major.

4. The assignment must be approved by the Office of Cooperative Education, in conjunction with the student's faculty advisor and department chair.

5. The assignment must meet the usual requirements of the co-op program; i.e., must primarily involve Engineering/Computer Science experience; student must meet prerequisite and GPA requirements, etc.

6. Student must have regularly scheduled and direct supervision by a degreed engineer/CS professional (on-site, off-site, or faculty mentor at Pacific)

7. Student must satisfy all normal co-op reporting requirements (e.g., submittal of a progress report and final report).

8. A service-oriented SOECS co-op assignment may only be used for a maximum of 16 units.

These criteria provide guidance to the students, faculty, staff involved in the co-op program, and to the organizations at which the students work. Criterion 8 ensures that each student also develops their skills in researching, applying and interviewing for, and working in a more 'traditional' engineering co-op at a public or private organization either in the U.S. or abroad. Application of these criteria ensured that all of the students' experiences in working with the non-governmental organizations listed in Table 1 qualified as an acceptable co-op experience. Students who needed co-op units were able to earn units to meet graduation requirements. Due to compact curriculum plans, at least three of the students were able to take advantage of the opportunities to work with the non-governmental organizations only because the experience also met co-op unit requirements. Working within the framework of the co-operative education program allowed students stay on schedule to meet their planned graduation date, follow established and familiar practices similar to those followed during their previous co-op experiences, and access resources available in the Office of Co-operative Education. 


\section{Learning Outcomes and Assessment}

Learning outcomes of the well-established co-operative education program were used as a basis for the learning outcomes specifically developed for engineering participants in the Ambassador Corps Fellowship Program. Engineering students who received fellowships in 2010 and 2011 submitted a post-trip report that included a description of their tasks and overall experience, analysis of what made the organization entrepreneurial, and an evaluation of how the student's experience affected their decision to pursue engineering. The following set of learning outcomes was distributed to the students prior to their departure and each was asked to specifically address the outcomes in their report:

- Explain the role of culture, interpersonal communication, and other professional skills in working in the non-profit/social entrepreneurship sector

O Explain how your knowledge, skills and attitudes helped or hindered you in your assignment

- Explain how you adapted (if you did) and what the outcomes were, what facilitated that adaptation, and what you could have or should have done differently.

- Explain the application of engineering and other principles towards solution of critical societal issues related to your specific experience (e.g., water, sanitation, housing, wildlife conservation)

- Explain the role of academic preparation and engineering studies in preparing students (you) for work in the non-profit/social entrepreneurship sector

- Propose areas for improvement in your academic (technical and non-technical) and professional preparation that relate to your fellowship experience

- Propose practices and processes (appropriate to University of the Pacific) that can facilitate transitions, training, and recruiting of students for global experience

In 2010 and 2011, post-trip debriefing sessions were conducted to learn about the students' experiences, to help them put their experiences in perspective as related to their engineering education, and to identify strengths of the internship program and areas for improvement. A rubric, shown in Table 3, was developed to assess the level of achievement of learning outcomes within the context of the program, as documented in the students' reports. Because the rubric was developed after the reports were written in 2010 and the sample size was small - three students in 2010 and one student in 2011 - it was not as useful a tool as anticipated for assessing effectiveness of the summer internship program, but did allow for systematic assessment of students' reflections on their experiences.

Interpersonal communication, both verbal and non-verbal, was cited as the most important skill used and the skill most enhanced as a result of the experience - likely due to the fact that each student was required to communicate in a new environment, addressing language barriers and different cultural practices. Qualities particularly relevant to working with a social entrepreneurship organization were empathy for the people or the community they served, adaptability, humility, and a sense of humor. Students felt they would have benefitted from additional research on politics and cultural norms specific to their host country. 


\section{Table 3. Assessment Rubric for Ambassador Corps Fellowship Program}

\begin{tabular}{|c|c|c|c|}
\hline CATEGORY & Exemplary & Accomplished & Developing \\
\hline $\begin{array}{l}\text { Role of professional } \\
\text { skills in non-profit } \\
\text { sector }\end{array}$ & $\begin{array}{l}\text { Role of professional skills } \\
\text { explained clearly. Several } \\
\text { relevant details and/or } \\
\text { examples given. }\end{array}$ & $\begin{array}{l}\text { Role of professional skills } \\
\text { explained. 1-2 relevant details } \\
\text { and/or examples given. }\end{array}$ & $\begin{array}{l}\text { Role of professional skills } \\
\text { explained briefly. No relevant } \\
\text { details and/or examples given. }\end{array}$ \\
\hline $\begin{array}{l}\text { Role of knowledge, } \\
\text { skills, attitudes }\end{array}$ & $\begin{array}{l}\text { Role of knowledge, skills, } \\
\text { attitudes explained clearly. } \\
\text { Several relevant details and/or } \\
\text { examples given. }\end{array}$ & $\begin{array}{l}\text { Role of knowledge, skills, } \\
\text { attitudes explained. 1-2 } \\
\text { relevant details and/or } \\
\text { examples given. }\end{array}$ & $\begin{array}{l}\text { Role of knowledge, skills, } \\
\text { attitudes explained briefly. No } \\
\text { relevant details and/or } \\
\text { examples given. }\end{array}$ \\
\hline Role of adaptation & $\begin{array}{l}\text { Clearly explains role of } \\
\text { adaptation, reflected on } \\
\text { experience. Several relevant } \\
\text { details and/or examples given. }\end{array}$ & $\begin{array}{l}\text { Explains role of adaptation, } \\
\text { reflected on experience. A few } \\
\text { relevant details and/or } \\
\text { examples given. }\end{array}$ & $\begin{array}{l}\text { Explains role of adaptation, no } \\
\text { reflection on experience. No } \\
\text { details and/or examples given. }\end{array}$ \\
\hline $\begin{array}{l}\text { Role of engineering in } \\
\text { societal context }\end{array}$ & $\begin{array}{l}\text { Clearly explains role of } \\
\text { engineering as it relates to the } \\
\text { experience. Several relevant } \\
\text { details and/or examples given }\end{array}$ & $\begin{array}{l}\text { Explains role of engineering, } \\
\text { briefly relates to experience. A } \\
\text { few relevant details and/or } \\
\text { examples given. }\end{array}$ & $\begin{array}{l}\text { Explains role of engineering, } \\
\text { not related to experience. No } \\
\text { details and/or examples are } \\
\text { given. }\end{array}$ \\
\hline $\begin{array}{l}\text { Usefulness of academic } \\
\text { preparation }\end{array}$ & $\begin{array}{l}\text { Clearly explains role of } \\
\text { preparation, reflected on role } \\
\text { as it relates to the non-profit } \\
\text { sector. Several relevant details } \\
\text { and/or examples given. }\end{array}$ & $\begin{array}{l}\text { Explains role of preparation, } \\
\text { briefly relates to the non-profit } \\
\text { sector. A few relevant details } \\
\text { and/or examples given. }\end{array}$ & $\begin{array}{l}\text { Explains role of preparation, } \\
\text { does not relate to the non- } \\
\text { profit sector. No details and/or } \\
\text { examples are given. }\end{array}$ \\
\hline $\begin{array}{l}\text { Areas for improvement } \\
\text { in academic preparation }\end{array}$ & $\begin{array}{l}\text { Specific areas for } \\
\text { improvement identified, } \\
\text { several supporting examples } \\
\text { given. }\end{array}$ & $\begin{array}{l}\text { General areas for improvement } \\
\text { identified, a few supporting } \\
\text { examples given. }\end{array}$ & $\begin{array}{l}\text { General areas for improvement } \\
\text { identified, no supporting } \\
\text { examples given. }\end{array}$ \\
\hline $\begin{array}{l}\text { Areas for improvement } \\
\text { in training, transitions }\end{array}$ & $\begin{array}{l}\text { Specific areas for } \\
\text { improvement identified, } \\
\text { several supporting examples } \\
\text { given. }\end{array}$ & $\begin{array}{l}\text { General areas for improvement } \\
\text { identified, a few supporting } \\
\text { examples given. }\end{array}$ & $\begin{array}{l}\text { General areas for improvement } \\
\text { identified, no supporting } \\
\text { examples given }\end{array}$ \\
\hline $\begin{array}{l}\text { Quality of written } \\
\text { report - mechanics }\end{array}$ & $\begin{array}{l}\text { No grammatical, spelling or } \\
\text { punctuation errors. }\end{array}$ & $\begin{array}{l}\text { Few grammatical, spelling or } \\
\text { punctuation errors }\end{array}$ & $\begin{array}{l}\text { Several grammatical spelling, } \\
\text { or punctuation errors. Needs } \\
\text { significant editing. }\end{array}$ \\
\hline $\begin{array}{l}\text { Quality of written } \\
\text { report - organization } \\
\text { and structure }\end{array}$ & $\begin{array}{l}\text { All paragraphs include } \\
\text { introductory sentence, } \\
\text { explanations or details, and } \\
\text { concluding sentence. Complex } \\
\text { and varied sentence structure } \\
\text { used. }\end{array}$ & $\begin{array}{l}\text { Most paragraphs include } \\
\text { introductory sentence, } \\
\text { explanations or details, and } \\
\text { concluding sentence. }\end{array}$ & $\begin{array}{l}\text { Paragraphs included related } \\
\text { information but were typically } \\
\text { not constructed well. }\end{array}$ \\
\hline
\end{tabular}

Students were not initially able to identify engineering skills and knowledge as being applicable to some of their tasks, particularly those that seemed relatively easy, for example, gathering, collating, and analyzing data or information, or planning and implementing a program. However, they were able to explain how their engineering knowledge helped them understand critical needs and issues related to water, sanitation, housing and to identify processes to address these critical needs. When engineering was considered in the broader context of problemsolving and developing products and processes to meet human or global needs, students were 
able to identify relevant technical and professional skills that they did apply and skills they developed while working with their respective organizations, as shown in Table 2.

Although all of the students had completed at least five months of co-op in the public or private sectors in the U.S. prior to their experiences at the social entrepreneurship organizations, they were challenged by their lack of engineering experience. Unlike more 'traditional' co-op experiences where students were directly supervised and mentored by one or more engineers, supervisors and colleagues in the social entrepreneurship organizations typically had nontechnical backgrounds, and most of the technical guidance was provided by their faculty supervisor. Students noted that their academic background and prior co-op experiences had not prepared them sufficiently to work in the non-profit sector or in emerging countries, specifically, where resources are scarce or where different types of resources are used.

One limitation of the eight-week Ambassador Corps experience is that the internships may not provide sufficient time for the student to adapt to the local culture and the host organization, become familiar with the work being performed, apply the necessary skills, and either see the project to completion or make sufficient progress to feel that their efforts were of use to the host organization. Longer internship durations may help increase the students' level of confidence in their contributions. Although the students seemed to feel that their contributions were somewhat lacking in substance, feedback on students' performance provided by supervisors at each of the host organizations was consistently positive. A measure of the program success is demonstrated by the fact that three of the host organizations have since hosted other Pacific engineering students for internships.

One student suggested, and others concurred, that an elective or project-based course focused on engineering in the context of social entrepreneurship or in emerging countries would have better prepared them for the experience. Such a project-based course is not currently feasible as a stand-alone course given the limited level of student interest and constraints on faculty time and students' curricula. From an institutional perspective, important lessons learned from this experience are that developing strategic partnerships and using existing frameworks are keys to developing successful - and sustainable - programs. Consideration of models used at other universities ${ }^{17,23}$ may help identify a model that is responsive to the opportunities and challenges unique to the University of the Pacific.

\section{CONCLUSIONS}

Schools of engineering recognize student interest in service-focused work, the interest of some students in going abroad, and of the need to provide students with a broad-based education transcending traditional engineering subjects. Service learning programs are a natural means of satisfying ABET requirements and meeting student interest. However, initiatives outside the mainstream are sometimes stymied by a lack of resources or are dependent on the energy of an individual faculty member for long-term sustainability. These factors at best jeopardize, but often become insurmountable barriers to, the viability of service-focused programs in engineering.

The Ambassador Corps Fellowship program and its role in engineering education demonstrate two key principles that can be applied at other institutions, namely, formation of strategic partnerships with other university entities and use or adaptation of existing frameworks, in this case, the co-operative education program, to facilitate student participation in the service learning experience. 
In the partnership between the School of Engineering and Computer Science and the Global Center at the University of the Pacific, the Global Center provides administrative support, logistical support and opportunities to network with social entrepreneurship organizations abroad. The SOECS provides students with skills that are eagerly sought-after by social entrepreneurship organizations, and faculty who provide expertise, planning assistance, and review of the program. Although not all institutions have such a Center, engineering programs can collaborate with other academic or administrative units, e.g., business, international studies, or study abroad, to provide similar experiences. These other units can help identify partner organizations to host students or provide logistical support for students travelling abroad functions that engineering may not have the capability or capacity to support. A successful collaboration will require flexibility on the part of all involved to identify how the partnership can benefit each group and a willingness to learn from one another.

Existing entities and frameworks, in this case, the Office of Co-operative Education and the co-operative education program, can provide a means by which engineering students can systematically participate in service-based or international internship programs. Flexibility within the co-op program allowed for adoption of a set of criteria by which the eligibility of a proposed experience could be evaluated. Development of the criteria in consultation with the Director of Co-operative Education ensured that the criteria would be acceptable to the Academic Standards Committee and that proposals that met eligibility criteria would receive the Director's support. This support in turn, enabled students to use this service-based internship to meet, in part, practical engineering experience requirements for graduation. The structure of the established co-op program provided faculty with guidelines for development and assessment of learning outcomes and provided students with additional resources - both human and information - upon which to draw. The students' unusual and engaging experiences have in turn benefitted the co-op program by increasing its visibility at the university and for prospective students. From the perspective of the School of Engineering and Computer Science, collaboration with the Global Center for Social Entrepreneurship provided the infrastructure and administrative needs (e.g., placement services, procedures, staff, training, student monitoring) for a type of service-focused internship experience that could not be supported by existing resources within the school. Such programs may not be practicable for or attractive to all students, but, for those students who are interested in such opportunities, these partnerships can pave the way for non-traditional and highly enriching experiences for all involved.

\section{ACKNOWLEDGEMENTS}

The authors gratefully acknowledge the Cordes and Peery Foundations for their generous support of the Ambassador Corps Fellowship program; Jerry Hildebrand, Executive Director, and Spencer Ton, Assistant Director, at the Global Center for Social Entrepreneurship for administering the program; the organizations and communities that hosted the students; and students Liza Boyle, Hayley Cook, Andria Ellis, Jocelyn Gray, Kristina Hammarstrom, Feliciano Leon, and Christina Ramirez for their willingness to embark on these internships and share their lessons learned. 
International Journal for Service Learning in Engineering

Vol. 7, No. 1, pp. 40-52, Spring 2012

ISSN 1555-9033

\section{REFERENCES}

1 National Academy of Engineering, The Engineer of 2020: Visions of Engineering in the New Century. National Academies Press, 2004.

2 ABET Engineering Accreditation Commission, Criteria for Accrediting Engineering Programs, 2010-11 Accreditation Cycle. ABET Inc., Baltimore, MD.

3 http://d-lab.mit.edu. Accessed 1/2011.

4 McGarvey, K., M. Biggs, J. Hill, M. Panko, N. Bacher, and B. Sukumaran. "Engineering Innovators without Borders: Developing Entrepreneurial Opportunities for the Developing World through Engineering Redesign," International Journal for Service Learning in Engineering, Vol. 4, No. 1, pp. 48-61, 2009.

5 Magoon, C., K. Villars, J. Evans, B. Hickey, A. Sayre, C. Tutino, and R. J. Swap. "Water Supply and Treatment Design in Rural Belize: A Participatory Approach to Engineering Action Research," International Journal for Service Learning in Engineering, Vol. 5, No. 1, pp. 47-63, 2010.

6 Estell, J., K. Reid, and J. Marquart. "Addressing Third World Poverty in First-Year Engineering Capstone Projects: Initial Findings," Paper AC-2010-197, Proceedings of the 2010 ASEE Conference and Exposition, 2010.

7 http://engineering.purdue.edu/EPICS. Accessed 1/2011.

8 Coyle, E., L. Jamieson, and W. Oakes. "EPICS: Engineering Projects in Community Service," International Journal of Engineering Education, Vol. 21, No. 1, 2005.

9 Gonzalez, E., E. Heisman, and G. Lucko. "Student-Centered Learning Environment for Disaster-Mitigating Engineering Design and Deployment in Developing Regions," International Journal for Service Learning in Engineering, Vol. 5, No.1, pp. 189-209, 2010.

10 Loendorf, W., D. Richeter, and D. Teachman. "Results from and Interdisciplinary Service Learning Pilot Project Incorporating Universal Design for ADA Compliance," Paper AC-2010-1010, Proceedings of the 2010 ASEE Conference and Exposition, 2010.

11 Mehta, Y., and B.Sukumaran. "Integrating Service Learning in Engineering Clinics," International Journal for Service Learning, Vol. 2, No. 1, pp. 32-43, 2007.

12 Amadei, B., and R. Sandekian. "Model of Integrating Humanitarian Development into Engineering Education," Journal of Professional Issues in Engineering Education and Practice, Vol. 136, No. 2, 2010.

13 Global Perspective Program at WPI: http://www.wpi.edu/Academics/GPP/, Accessed 1/2011.

14 Dave, J., and J. Dong. "Global Experiential Learning for Engineering Technology Students," Paper AC-20101718, Proceedings of the 2010 ASEE Conference and Exposition, 2010.

15 Barrington, L. and J. Duffy. “Maximizing Benefits of Service Learning in Engineering," Paper AC-2010-2149, Proceedings of the 2010 ASEE Conference and Exposition, 2010.

16 Eyler, J., and D. E. Giles. Where's the Learning in Service Learning? Jossey-Bass, San Francsico, 1999.

17 Borg, J, and D. H. Zitomer, "Dual-Team Model for International Service Learning in Engineering: Remote Solar Water Pumping in Guatemala," J. Professional Issues in Engineering. Education and Practice, Volume 134, Issue 2, pp. 178-185, April 2008.

18 Jue, D. "Improving the Long-Term Sustainability of Service-Learning Projects: Six Lessons Learned from Early MIT IDEAS Competition Winners." International Journal for Service Learning in Engineering, Vol. 6, No. 2, pp. 19-29, Fall 2011.

19 Saviz, C., A. Fernandez, E. Basha, A Ellis, K Hammarstrom, F. Leon, J. Hildebrand, and S. Ton. "Engineering Internships in Social Entrepreneurship: Developing Partnerships and Student Perspectives" Paper AC 2011748, proceedings of the 2011 ASEE Annual Conference, Vancouver, BC, Canada, June 26-29, 2011.

$20 \mathrm{http} / / / \mathrm{www}$. ewb-usa.org.

21 http://www.esustainableworld.org.

22 Ogunyoku, T. A., D. M. Nover, E. R. McKenzie, G. Joshi, and W. E. Fleenor. "Point-Of-Use Drinking Water Treatment in the Developing World: Community Acceptance, Project Monitoring and Revision," International Journal for Service Learning in Engineering, Vol. 6, No. 1, pp. 14-32, Spring 2011.

23 Budny, D. and R. T. Gradoville. "International Service Learning Design Projects: Educating Tomorrow's Engineers, Serving the Global Community, and Helping to Meet ABET Criterion," International Journal for Service Learning in Engineering, Vol. 6, No. 2, pp. 98-117, Fall 2011.

$24 \mathrm{http} / / / \mathrm{www} . c s u f r e s n o . e d u / p a r e n t s / \mathrm{blog} /$ ?tag=community-service-scholarship-program. Accessed 3/2012.

25 Derousi, P., and C. S. Sherwood. "Community Service Scholarships: Combining Cooperative Education with Service Learning" Journal of Cooperative Education, Vol. 33, Issue 1, pp. 46-55. 
Paterson, K., C. O'Holleran, and C. Leslie. "Faculty Impressions of Service Learning in Engineering Education," Paper AC-2010-2033, Proceedings of the 2010 ASEE Conference and Exposition, 2010.

27 Fridley, K. "Today's BSCE: A Survey of Credit Hour Requirements," Paper AC 2011-1436, Proceedings of the 2011 ASEE Annual Conference, Vancouver, BC, Canada, June 26-29, 2011.

28 Martin, G. "Professional Practice Seminar: A successful course for preparing students for their Cooperative Education Experiences," Proceedings of the 2003 ASEE Annual Conference, 2003. 